\title{
Tingkat Penerapan Biosekuriti Pada Peternakan Ayam Petelur Di Kecamatan Panca Rijang Kabupaten Sidrap
}

\author{
Level of Application of Biosecurity in Laying Farms \\ in Panca Rijang Subdistrict Sidrap Regency \\ Rasyidah Mappanganro*, Jumriah Syam, Chaedar Ali \\ Jurusan Ilmu Peternakan Fakultas Sains dan Teknologi \\ Universitas Islam Negeri Alauddin Makassar \\ *Korespondensi E-Mail : rasyidah.mappanganro@uin-alauddin.ac.id
}

\begin{abstract}
ABSTRAK
Penelitian ini bertujuan untuk mengetahui tingkat penerapan biosecuriti pada paternakan ayam petelur di Kec. Panca Rijang Kab. Sidrap. Penelitian ini adalah field research(penelitian lapangan), menggunakan pendekatan kuantitatif dengan metode survey yang fokus pada metode sampel, pengamatan serta wawancara untuk melengkapi data survey. Penelitian ini dilaksanakan pada bulan Maret - April 2018 di Kec. Panca Rijang Kab. Sidrap. Pengumpulan data dalam penelitian ini menggunakan skala Guttman yaitu untuk mengetahui respon responden yang tegas terhadap dua alternatif. Komponen biosecuriti yang dinilai meliputi penarapan isolasi, sanitasi dan pengawasan lalu lintas. Hasil penelitian menunjukkan bahwa tingkat penerapan isolasi sebesar $61,24 \%$, penerapan sanitasi sebesar77,38\%, dan penerapan pengawasan lalu lintas sebesar $77,06 \%$.
\end{abstract}

Kata kunci: Biosekuriti, Ayam Petelur, Peternak

\begin{abstract}
This reasearch were aimed to determine the level of application of biosecurity in laying farms in Panca Rijang Subdistrict, Sidrap Regency. This research is field research (field research), using a quantitative approach with survey methods that focus on sample methods, observations and interviews to complete survey data. This research was carried out in March - April 2018 in the the district of Panca Rijang, Sidrap Regency. Data collection in this study uses the Guttman scale which is to find out the respondent's firm response to two alternatives. The biosecurity components assessed include the expectation of isolation, sanitation and traffic control. The results showed that the level of application of isolation was $61.24 \%$, the application of sanitation was $77.38 \%$, and the application of traffic control was $77.06 \%$.
\end{abstract}

Keywords: Biosecurity, Breeders, Layer

\section{PENDAHULUAN}

Ayam ras petelur merupakan jenis ayam yang memiliki laju pertumbuhan sangat pesat dan kemampuan berproduksi telur yang tinggi. Sifat-sifat unggul yang dimiliki ayam 
ras petelur antara lain laju pertumbuhan ayam ras petelursangat pesat pada umur 4,5-5,0 bulan, kemampuan produksi telur ayam raspetelur cukup tinggi yaitu antara 250-280 butir/tahun dengan bobot telur antara 50 gram-60 gram/tahun, konversi terhadap penggunaan ransum cukup bagus yaitu setiap 2,2 $\mathrm{kg}-2,5 \mathrm{~kg}$ ransum dapat menghasilkan 1 $\mathrm{kg}$ telur, dan periode ayam ras petelur lebih panjang karena tidak adanya periode mengeram (Sudarmono, 2003). Bahkan untuk jenis leghorn dapat mencapai 284 sampai 300 butir pertahun (Yuwanta, 2010). Umumnya produksi kualitas telur yang terbaik akan diperoleh pada tahun pertama ayam mulai bertelur dan produksi dan kualitas telur pada tahun-tahun berikutnya cenderung akan terus menurun seiring semakin tua umur ayam (Hafez, 2000). Pemeliharaan ayam petelur pada umumnya dibagi tiga fase pemeliharaan berdasarkan umur, yaitu fase starter, fase grower, dan fase layer. Fase pra layer atau pullet ayam berumur 12 minggu sampai 20 minggu. Fase ini memerlukan penanganan yang lebih serius, sebab pada fase ini sangat menentukan produktifitas ayam petelur. Fase layer adalah fase dimana tujuan utamanya untuk menghasilkan telur. Fase ini ayam sudah mengalami dewasa kelamin biasanya berumur 20 - 21 minggu. Pemeliharaan fase layer merupakan fase kelanjutan dari fase pullet, hasil dari pemeliharaan sebelumnya akan terlihat pada saat ayam bertelur pertama kali. Bahkan beberapa tindakan yang dapat merubah lingkungan kandang sangat berpengaruh terhadap produktivitas ayam.Produktivitas ayam petelur dapat ditingkatkan diantaranya dengan memperbaiki manajemen pemeliharaan, pakan, pencegahan, dan penanggulangan penyakit.

Biosekuriti merupakan garda terdepan dalam mengamankan ternak dari penyakit. Peternakan yang menerapkan program biosekuriti akan bisa menekan biaya kesehatan ternak menjadi lebih murah dibanding peternakan yang tidak menerapkan biosekuriti. Karena penanganan penyakit jika sudah terjadi outbreak dalam sebuah peternakan tentu akan mengahabiskan banyak biaya.Program ini cukup murah dan efektif dalam mencegah dan mengendalikan penyakit. Bahkan tidak satupun program pencegahan penyakit dapat bekerja dengan baik tanpa disertai program biosekuriti (Direktorat Pembinaan Sekolah Menengah Kejuruan, 2014). Biosekuriti mencakup tiga hal utama yang harus diperhatikan oleh peternak yaitu isolasi, pengendalian lalu lintas dan sanitasi. Isolasi berarti menjauhkan ayam dari orang, kendaraan dan benda yang dapat membawa patogen. Menciptakan lingkungan tempat ayam terlindung dari pembawa bakteri patogen (orang, hewan lain, udara dan air).Pengendalian lalu lintas diupayakan untuk men-screening orang, alat, barang 
dan hewan lain, agar kegiatan lalu lintas yang dilakukannya tidak menyebabkan masuknya patogen ke dalam farm (Johari, 2004).Sanitasi merupakan tindakan pembersihan (cleaning) dan desinfeksi untuk membunuh kuman. Sanitasi juga berarti upaya pengendalian hama yang bertujuan untuk mencegah hama (burung liar, hewan pengerat dan serangga) membawa patogen.

Kabupaten Sidrap merupakan salah satu daerah di Provinsi Sulawesi Selatan yang menjadi sektor perekonomian, khususnya pertanian dan peternakan. Kabupaten Sidrap adalah wilayah peternakan yang menjadi wilayah pengembangan usaha unggas ayam petelur. Dimana Kabupaten Sidrap menjadi Kabupaten yang mempunyai produksi telur terbesar di Sulawesi Selatan dengan jumlah 45. 407 336./kg (Badan Pusat Statistik,2015). Berdasarkan hal tersebut, maka penelitian mengenai bagaimana tingkat penerapan biosekuriti pada usaha peternakan ayam petelur di sentra produksi telur menjadi sangat penting. Berdasarkan permasalahan diatas maka, penelitian ini bertujuan untuk mengetahui tingkat penerapan biosekuriti isolasi, sanitasi dan pengawasan lalu lintas pada usaha peternakan ayam petelur di Kec. Panca Rijang, Kab. Sidrap

\section{METODE}

\section{Populasi dan Sampel Penelitian}

Populasi dalam penelitian ini adalah peternakan ayam petelur yang berada di Kec. Panca Rijang yang berjumlah 85. Penentuan sampel (responden) dilakukan secara purposive sampel. Jumlah sampel ditentukan dengan menggunakan metode Slovin dalam Umar (2008) dengan rumus sebagai berikut :

Keterangan :

$$
n=\frac{N}{1+N(e)^{2}}
$$

$\mathrm{n}=$ Sampel

$\mathrm{N}=$ Populasi

e $=$ Tingkat Kegagalan $10 \%$

\section{Metode Pengumpulan Data}

Metode yang digunakan dalam penelitian ini adalah metode survey, instrument penelitian ini adalah kuesioner, pengamatan dan wawancara. Sumber data penelitian, adalah 1) Data primer, yaitu data yang diperoleh langsung dari responden menggunakan kuesioner, pengamatan dan wawancara, dan 2) Data sekunder, yaitu data pendukung yang 
diperoleh dari istansi-istansi terkait, Biro statistik, pemerintah setempat dan lain-lain yang telah tersedia yang ada kaitanya dengan penelitian ini.

\section{Instrument penelitian}

Instrument penelitian ini menggunakan kuesioner yang isinya berupa pertanyaan/pernyataan secara terstruktur, pilihan pilihan jawaban secara tertutup menggunakan skala pengukuran yaitu skala Guttman. Skala Guttman digunakan untuk mengetahui respon responden yang tegas terhadap dua alternatif. Dalam penelitian ini, menggunakan skala 1-2, dimana jawaban : 1 = Tidak $: 2=$ Ya.

\section{Teknik Pengolahan dan Analisis Data}

Analisis statistik berdasarkan persentase (\%) untuk mengetahui tingkat penerapan biosecuriti di peternakan ayam petelur pada variabel/indikator: isolasi, sanitasi, dan pengawasan lalu lintas.

\section{HASIL DAN PEMBAHASAN}

\section{Tingkat Penerapan Biosekuriti pada Peternakan Ayam Petelur di Kecamatan Panca Rijang}

Tindakan biosekuriti memiliki 3 komponen utama, yaitu isolasi ternak dari lingkungan luar, dan pengawasan lalu lintas dalam peternakan dan sanitasi (Jeffrey 2006). Implementasi biosekuriti yang diamati padapenelitianinimeliputi:

\section{Tingkat Penerapan Isolasi}

Isolasi berarti menjauhkan ayam dari orang, kendaraan dan benda yang dapat membawapatogen. Menciptakan lingkungan tempat ayam terlindung dari pembawa bakteripatogen (orang, hewan lain, udara dan air) (Johari, 2004).Isolasi merupakan bagian komponen utama biosekuriti. Isolasi merupakan pemisahan hewan agar dalam suatu lingkungan terkendali sehingga mencegah munculnya agen penyakit. Implementasi Biosecuriti dalam hal Isolasi yang menerapkan terbanyak pada Penerapan Adanya pagar pembatas antara peternakan dengan lingkungan luar sebesar 91.49\%, dan yang tidak menerapkan yaitu pada Jarak lokasi kandang dengan rumah penduduk minimal 1000m sebesar $91.48 \%$. Hal ini berarti peternak memiliki kesadaran untuk memagari kandangnya agar terhindar dari berbagai macam agen penyakit, Sesuai dengan Pendapat (Direktorat Pembinaan Sekolah Menengah Kejuruan, 2014).Pembuatan pagar di sekeliling peternakan 
untuk mengendalikan lalu lintas manusia dan hewan lain. Implementasi isolasi berdasarkan beberapa indikator dapat jelaskan sebagai berikut :

a. Adanya Pagar Pembatas antara Peternakan dengan Lingkungan Luar

Pagar pembatas merupakan salah satu cara mencegah masuknya hewan liar dan orang yang tidak berkepentingan. Hal ini bertujuan untuk mengurangi penyebaran penyakit. Berdasarkan grafik di atas dapat diketahui bahwa sebagian besar peternak di Kecamatan Panca Rijang memilki pembatas antara peternakan dengan lingkungan luar. Dimana total yang menerapkan pagar pembatas antara peternakan dengan lingkungan luar sebesar 91.49\%. Pintu gerbang suatu peternakan adalah tempat pertama bagi orang yang mau masuk ke areal atau komplek peternakan dan merupakan titik awal keberhasilan suatu peternakan terbebas dari wabah atau serangan penyakit. mengkondisikan setiap orang maupun kendaraan tidak sembarangan keluar masuk Farm, dan pintu selalu dijaga ketat oleh petugas (Direktorat Pembinaan Sekolah Menengah Kejuruan, 2014). Sehingga lokasi peternakan harus berpagar dengan satu pintu masuk rumah tempat tinggal, kandang unggas serta kandang hewan lainnya ditata pada lokasi terpisah. Kesadaran peternak dalam melaksanakan biosekuriti pagar pembatas dengan lingkungan luar sudah sangat tinggi, namun ada beberapa peternak yang belum menerapkan hal tersebut diakibatkan faktor biaya untuk membeli bahan memagari sekeliling kandangnya.

\section{b. Adanya Pemisah antara Hewan yang Sakit dengan yang Sehat}

Unggas yang sakit atau menunjukkan gejala sakit harus dipisahkan dengan unggas yang sehat. Hal ini bertujuan untuk mengurangi penyebaran agen penyakit. Berdasarkan grafik di atas dapat diketahui bahwa sebagian besar peternak di Kecamatan Panca Rijang tidak menerapkan pemisahan hewan yang sakit dan sehat. Data menunjukkan bahwa jumlah yang tidak menerapkan pemisahan hewan sakit dan sehat yaitu sebesar $70.21 \%$.Unggas sakit atau menunjukkan gejala sakit harus dipisahkan dengan unggas sehat. Unggas sakit berpotensi membawa agen penyakit dan unggas di sekitarnya merupakan hewan rentan terhadap virus Avian Influenza. Seperti diketahui bahwa menularnya virus Avian Influenza dari unggas ke unggas lainnya bisa melalui kontak langsung atau melalui droplet aerosol dan feses unggas yang sakit (Ditjen Peternakan 2005). Selain itu, apabila terjadi kasus penyakit maka isolasi terhadap hewan atau kelompok hewan sakit harus segera dilaksanakan secepat mungkin untuk menghentikan penyebaran penyakit. Hal ini berarti 
peternak masih kurang menyadari akan pentingnya Biosecuriti Pemisahan hewan yang sakit dan sehat, sehingga resiko penyebaran penyakit hewan yang sakit akan mudah tersebar.

c. Adanya Pemisah antara Kandang dengan Rumah Tinggal

Manusia merupakan salah satu agen pembawa penyakit. Maka harus tinggal terpisah dengan kandang. Hal ini bertujuan untuk mencegah penyebaran agen penyakit. Berdasarkan grafik di atas dapat diketahui bahwa sebagian besar peternak di Kecamatan Panca Rijang menerapkan Adanya Pemisah antara kandang dengan rumah tinggal. Data menunjukkan bahwa jumlah yang menerapkan Adanya Pemisah antara kandang dengan rumah tinggal yaitu sebesar 91.48\%. Aktivitas pekerja kandang di sekitar kandang dapat mengganggu kesehatan ayam. Program biosekuriti meliputi pengendalian pergerakan hewan, peralatan, orang - orang dan sarana pengangkutan dari luar dan ke farm yang satu ke farm yang lain (Grimes danJackson, 2001). Hal ini berarti peternak telah menyadari pentingnya Biosecuriti Pemisah antara Kandang dengan rumah tinggal, agar area kandang tidak mudah terserang penyakit. Namun, ada beberapa peternak yang belum menerapkan hal tersebut, diakibatkan lokasi kandang yang sempit dan berada tepat di belakang rumah peternak.

\section{d. Jarak Lokasi Kandang dengan Rumah Penduduk Minimal 1000 m}

Lokasi Kandang merupakan hal yang sangat penting dalam usaha peternakan ayam petelur. Lokasi kandang harus jauh dari rumah penduduk agar terhindar dari penyakit, karena ayam rentan akan stress dan dapat menyebabkan ayam terkena penyakit. Berdasarkan grafik di atas dapat diketahui bahwa sebagian besar peternak di Kecamatan Panca Rijang tidak memiliki Jarak Lokasi Kandang dengan rumah penduduk minimal 1000m. Data menunjukkan bahwa jumlah yang tidak memiliki Jarak Lokasi Kandang dengan rumah penduduk minimal 1000m yaitu sebesar 91.48\%.Tindakan isolasi meliputi; menjaga jarak minimum antara peternakan unggas sekitar 400-1000 meter, pengandangan unggas di dalam lingkungan yang terkendali, pembuatan kasa pemisah untuk menjaga agar ternak yang di pelihara tetap di dalam kandang dan hewan yang lain tetap di luar (unggas liar, anjing, kucing, tikus dll), pembuatan pagar di sekeliling peternakan untuk mengendalikan lalu lintas manusia dan hewan lain, pembuatan tanda-tanda peringatan, memisahkan unggas berdasarkan spesies karena unggas air berperan sebagai carrier virus flu burung, dan penerapan sistem manajemen all in all out (Direktorat Pembinaan Sekolah Menengah Kejuruan, 2014). Hal ini berarti Peternak belum menerapkan hal tersebut. Diakibatkan lahan peternakan yang terbatas dan mahal. Sehingga peternak memilih lokasi kandang sesuai 
batas kemampuannya. Modal menjadi kendala peternak untuk mencari lahan yang sesuai dengan standar.

e. Adanya Pembasmian Serangga, Tikus, Burung liar, ataupun Hewan Pengganggu lainnya.

Hewan penggangu merupakan agen pembawa penyakit yang membahayakan bagi peternakan sehingga harus dibasmi. Hal ini bertujuan agar tidak terjadi penyebaran agen penyakit. Berdasarkan grafik di atas dapat diketahui bahwa sebagian besar peternak di Kecamatan Panca Rijang melakukan pembasian hewan pengganggu Data menunjukkan bahwa jumlah yang menerapkan pembasmian hewan pengganggu yaitu $85.1 \%$. Hewan pengganggu seperti serangga, tikus dan burung liar menjadi agen penyakit ketika berada di dalam peternakan, sehingga hal ini menjadi penting untuk dibasmi. Menurut (Deptan RI, 2008) menyatakan bahwa mencegah keluar masuknya tikus (rodensia), serangga atau unggas lain seperti burung liar yang dapat berperan sebagai vektor penyakit ke lokasi peternakan. Hadi (2003) menambahkan agen penyakit bisa masuk melalui Terbawa oleh burung-burung liar, predator (kumbang), rodensia (tikus), lalat, caplak, tungau dan serangga lain. Burung liar merupakan reservoar bagi penyakit ND, IB, Psitakosis, influensa unggas dan Pasteurella spp. Kumbang merupakan reservoar sejumlah besar infeksi termasuk penyakit Marek, Gumboro, salmonellosis, pasteurellosis dan koksidiosis. Rodensia dapat menyebarkan berbagai ragam penyakit termasuk pasteurellosis dan salmonellosis. Lalat dapat menularkan berbagai bakteri penyebab penyakit pencernaan ayam dan virus cacar ayam (fowl pox). Caplak Argas dapat menjadi vektor pembawa spirokhetosis. Tungau Ornitonyssus bursa dapat menimbulkan gangguan produksi ayam dan kegatalan bagi karyawan, sedangkan Culicoides (agas atau mrutu) dapat menjadi vektor leucocytozoonosis yang cukup merugikan. Hal ini berarti peternak telah menyadari akan pentingnya hewan pengganggu sehingga tetap menjaga peternakannya akan serangan hewan pengganggu tersebut.

Namun, dalam hal ini, peternak ada yang tidak menerapkan hal tersebut disebabkan karena biaya dan sulit untuk dibasmi. Sesuai dengan pendapat Irawan (2007) Pada dasarnya tikus sangat sulit diberantas. Ini disebabkan ukuran tubuh tikus yang kecil dan tikus sangat aktif dalam pergerakannya. Ditunjang lagi habitat tikus di tempat yang gelap.Penanganan hama (insekta) dilakukan secara rutin, tidak hanya pada musim hama saja. Penyemprotan dengan bahan aktif pembasmi hama sangat efektif dilakukan, asal bahan aktif tersebut jangan sampai mengenai ayam-ayam atau tidak berbahaya bagi ayam-ayam tersebut. Untuk 
mengendalikan burung atau unggas liar, perlu dilakukan kerjasama dengan penduduk sekitar peternakan dengan cara menukar burung atau ayam peliharaan penduduk dengan ternak lain seperti kambing atau domba.

\section{Tingkat Penerapan Sanitasi}

Sanitasi merupakan hal yang utama dalam biosekuriti karena mencakup bagianbagian dalam kandang.Sanitasi ini meliputi praktek disinfeksi bahan, manusia, dan peralatan yang masuk ke dalam peternakan, serta kebersihan pegawai di peternakan (Jeffrey 1997). Sanitasi didefinisikan sebagai usaha pencegahan penyakit dengan cara menghilangkan atau mengatur faktor-faktor lingkungan yang berkaitan dalam rantai perpindahan penyakit tersebut. Penerapan dari prinsip-prinsip sanitasi adalah untuk memperbaiki, mempertahankan atau mengembalikan kesehatan yang baik pada ternak dan manusia. Prinsip sanitasi yaitu bersih secara fisik, bersih secara kimiawi (tidak mengandung bahan kimia yang membahayakan) dan bersih secara mikrobiologis. Hasil penelitian menunjukkan bahwa penerapan paling tinggi yaitu pada desinfeksi kandang DOC sebelum masuk 95.74\% dan Menjaga kebersihan sumber air 97.87\%. Dan yang belum menerapkan padadesinfeksi rak telur dan pakaian petugas kandang yaitu $55.31 \%$. Hal ini menunjukkan bahwa peternak menyadari akan pentingnya Desinfeksi kandang dan Menjaga Kebersihan sumber air. Menurut Abidin (2003) Biosekuriti merupakan tindakan yang sangat penting bagi kesehatan ayamagar produksinya tidak menurun dan ayam tersebut tetap terpelihara dengan baik(tidak mati). Menjaga kebersihan kandang merupakan salah satu langkah strategisuntuk mengurangi populasi bibit penyakit dalam sistem biosekuriti. Implementasi Sanitasi berdasarkan beberapa indicator dapat dijelaskan sebagai berikut :

\section{a. Desinfeksi Kandang Sebelum DOC Masuk}

Kandang merupakan tempat ayam untuk hidup, sehingga harus selalu dalam keadaan steril. Sebelum DOC masuk kandang harus didesinfeksi terlebih dahulu agar tidak menimbulkan penyakit. Hal ini bertujuan agar tidak terjadi penyebaran agen penyakit. Berdasarkan grafik di atas dapat diketahui bahwa sebagian besar peternak di Kecamatan Panca Rijang melakukan Desinfeksi kandang sebelum DOC masuk. Data menunjukkan bahwa jumlah yang menerapkan Desinfeksi kandang sebelum DOC masuk yaitu 95.74\%. Persiapan kandang sebelum DOC masuk harus steril dan telah dikukan desinfeksi agar menghindari adanya penyebaran penyakit. Menurut (Hadi, 2003) Agen penyakit bisa masuk melalui Terbawa masuk ketika anak ayam (DOC) datang (transmisi vertikal). Hal ini berarti 
peternak telah menyadari akan pentingnya Desinfeksi kandang sebelum DOC masuk agar tidak terjadi penyebaran penyakit. Penerapan dengan Sistem All-in all-out sangat untuk kandang DOC, agar kandang tetap steril dan tidak menimbulkan penyakit. Hal ini sesuai dengan pendapat (McGuire dan Scheideler 2005). Prinsip all-in all-out harus diperhatikan. Maksudnya adalah satu kandang hanya untuk satu jenis umur, tidak boleh dicampurcampur dengan berbagai umur lainnya. Seperti diketahui bahwa umur ayam yang masih muda dan yang sangat tua sangat rentan terkena penyakit. Oleh karena itu, jika seorang pekerja akan masuk ke dalam suatu kandang, diwajibkan dari umur yang termuda menuju umur yang lebih tua.Namun, beberapa peternak belum menerapkan hal tersebut diakibatkan kurangnya pengetahuan dan biaya untuk melakukan desinfeksi.

\section{b. Desinfeksi Tempat Pakan dan Air Minum Secara Teratur}

Tempat pakan dan air minum merupakan hal yang harus diperhatikan karena ayam tiap saat membutuhkan pakan dan minum. Seringkali ditempat pakan terdapat pakan yang menggumpal dan berjamur sehingga menimbulkan penyakit untuk ayam. Begitu pula dengan air minum, dimana air minum kebutuhan utama ayam untuk bertahan hidup. Desinfeksi tempat pakan dan air minum penting untuk tetap menjaga kesehatan ayam agar tidak menimbulkan agen penyakit. Berdasarkan grafik di atas dapat diketahui bahwa sebagian besar peternak di Kecamatan Panca Rijang melakukan Desinfeksi tempat pakan dan air minum secara teratur. Data menunjukkan bahwa jumlah yang menerapkan Desinfeksi Desinfeksi tempat pakan dan air minum secara teratur yaitu $74.46 \%$.

Tempat pakan dan air minum dapat menjadi sumber penyakit ketika tidak diperhatikan. Tempat pakan harus sering dikontrol agar tidak berjamur, begitupun air minum karena dapat memicu terjadinya pertumbuhan bakteri. Menurut (Hadi, 2003) Agen penyakit bisa masuk melalui Terbawa melalui makanan yang tercemar mikroorganisme di pabriknya. Kontaminasi bahan baku pakan atau pakan jadi dengan beberapa jenis patogen seperti Salmonella spp atau IBD/Gumboro dan paramyxovirus, Egg Drop Syndrom, Aflatoksin dapat menginfeksi kawanan unggas yang peka terhadap penyakit ini. Menular lewat air seperti berbagai jenis bakteri (Salmonella, Escherichia coli) dan fungi (Aspergillus). Hal ini berarti sebagian besar peternak telah menerapkan hal tersebut dan menyadari akan pentingnya menjaga kebersihan tempat pakan dan air minum. Jika dikaitkan dengan penyebaran virus Avian Influenza, kebersihan tempat pakan dan minum unggas memiliki peran dalam penyebarluasan virus Avian Influenza. Virus Avian Influenza dapat bertahan 
hidup di air selama 4 hari pada suhu $22^{\circ} \mathrm{C}$ atau 30 hari pada suhu $0^{\circ} \mathrm{C}$ (Depkes RI 2008). Air minum dan pakan yang kotor harus segera diganti untuk menghindari terjadinya kontaminasi atau penempelan penyakit (Soejoedono dan Handharyani 2005). Jeffrey (2006) menambahkan bahwa tempat air minum dan pakan yang bersih dapat mencegah suatu peternakan terserang virus Avian Influenza. Bahkan menurut Siahaan (2007), tempat pakan yang kotor menyebabkan risiko pemaparan Avian Influenza 5 kali lebih besar daripada tempat pakan yang bersih, sedangkan tempat minum yang kotor menyebabkan risiko pemaparan AI 4.85 kali lebih besar daripada tempat minum yang bersih.

\section{c. Membersihkan Kandang dan Sekelilingnya Secara Teratur}

Sanitasi kandang menjadi hal yang sangat penting dalam peternakan ayam petelur. Dengan melakukan penyemprotan desinfektan di sekitar kandang maka akan menimalisir terjadinya penyakit pada ayam. Berdasarkan grafik di atas dapat diketahui bahwa sebagian besar peternak di Kecamatan Panca Rijang melakukan Membersihkan kandang dan sekelilingnya secara teratur. Data menunjukkan bahwa jumlah yang menerapkan membersihkan kandang dan sekelilingnya secara teratur yaitu $74.46 \%$. Kandang sebagai tempat tinggal ayam harus selalu dijaga kebersihannya agar ayam nyaman tinggal dan terhindar dari penyakit. Sekitar kandang juga tidak luput dari kebersihan seperti rumput, tanaman, dan tempat-tempat yang bisa menimbulkan tumbuhnya agen penyakit. Maka dari itu pekerja kandang harus rutin membersihkan kandang dan sekelilingnya. Menurut (Deptan RI, 2008) kandang, tempat pakan/minum, sisa alas kandang/litter dan kotoran kandang dibersihkan secar teratur. Mendesinfeksi kandang-kandang dalam masa peralihan antarasatu periode ke periode berikutnya dan memiliki program pengendalian hama (Fadilah dan Polana, 2004). Menjaga kebersihan kandang merupakan salah satu langkah strategis untuk mengurangi populasi bibit penyakit dalam sistem biosekuriti. Karakteristik yang paling menonjol dari bibit penyakit adalah menyukai tempat kotor dan lembab sehingga menyebabkan mikroorganisme penyebab penyakit (mikroorganisme infeksius) dapat berkembang dengan cepat (Abidin, 2003). Hal ini berarti bahwa peternak telah menerapkan hal tersebut dan menyadari pentingnya menjaga kebersihan kandang. Siahaan (2007) menambahkan bahwa kandang yang kotor memberi peluang 12.44 kali lebih besar terpapar Avian Influenza dibandingkan dengan kandang yang yang bersih. 


\section{d. Desinfeksi Rak Telur dan Pakaian Petugas Kandang Secara Teratur}

Rak telur dan pakaian petugas kandang harus selalu di desinfeksi selama memasuki kandang karena berhubungan langsung dengan p-eternakan, rak telur yang dibeli diluar peternakan bisa jadi membawa penyakit dari luar. Sehingga menjadi untuk untuk dilakukan desinfeksi. Berdasarkan grafik di atas dapat diketahui bahwa peternak di Kecamatan Panca Rijang masih kurang yang menerapkan Desinfeksi rak telur dan petugas kandang secara teratur. Data menunjukkan sebanyak $44.68 \%$ yang menerapkan dan 55.31 yang tidak menerapkan. Pada dasarnya rak telur yang berasal dari luar peternakan tidak boleh dan sangat dilarang untuk masuk kembali ke dalam peternakan. Hal ini bertujuan untuk mencegah masuknya agen patogen yang berada di luar masuk ke dalam peternakan melalui rak telur. Rak telur yang telah berpindah berkali-kali dari satu peternakan ke peternakan lain tentu menjadi sumber agen patogen yang penting. Menurut (Hadi, 2003) menyatakan bahwa agen penyakit Terbawa melalui debu, bulu-bulu atau sayap, dan kotoran (manure) pada peralatan dan sarana lain seperti truk, kandang ayam, tempat telur dll. Hal ini berarti peternak belum menyadari akan pentingnya desinfeksi rak telur dan pakaian petugas kandang secara teratur. Namun, dalam hal ini peternak masih menggunakan rak yang terbuat dari bahan kertas sehingga menyulitkan untuk melakukan desinfeksi. Bahan yang dianjurkan adalah yang menggunakan plastik atau stainless steel karena kedua bahan ini mudah dibersihkan dan tidak cepat rusak (Marriott 1999).

\section{Pengawasan Lalu Lintas}

Pengendalian lalu lintas dalam suatu peternakan merupakan salah satu bagian penting dari biosekuriti.Pengendalian lalu lintas diupayakan untuk men-screening orang, alat,barang dan hewan lain, agar kegiatan lalu lintas yang dilakukannya tidakmenyebabkan masuknya patogen ke dalam farm (Johari, 2004).Tindakan pengendalian dilakukan terhadap segala sesuatu yang keluar atau masuk dalam suatu kandang/peternakan, mencakup lalu lintas manusia/peternak, peralatan, unggas/hewannya dan kendaraan. Berdasarkan hasil penelitian diketahui bahwa penerapanpengawasan lalu lintas hampir seluruh indikator menerapkan hal tersebut, yaitu tanda larangan masuk 89.36\%, Tidak membawa Unggas ke kandang tetangga dan tidak meminjamkan peralatan dengan peternak lainnya sebesar 97.87\%. Adapun yang tidak menerapakan yaitu pada Desinfeksi kendaraan dan peralatan sebelum masuk sebesar $61.7 \%$. Hal ini menunjukkan bahwa penerapanpengawasan lalu lintas telah diketahui oleh peternak dan menyadari akan pentingnya hal tersebut. Kontrol 
lalu lintas merupakan tindakan pencegahan penularan penyakit yang dibawa oleh alat angkut, hewan selain ternak (kuda, anjing, kucing, hewan liar, rodensia, dan burung), dan pengunjung. Kontrol lalu lintas di peternakan harus dibuat dengan baik untuk menghentikan atau meminimalkan kontaminasi pada hewan, pakan, dan peralatan yang digunakan. Alat angkut dan petugas tidak boleh keluar dari area penanganan hewan yang mati tanpa melakukan pembersihan (cleaning) dan desinfeksi terlebih dahulu (Swacita, 2017).

\section{a. Adanya Desinfeksi Terhadap Pengunjung/Petugas yang Masuk}

Setiap pengunjung yang memasuki area peternakan wajib melakukan desinfeksi terlebih dahulu agar menghindari penyebaran penyakit dari luar peternakan.Berdasarkan grafikdiatas diketahui penerapan Desinfeksi terhadap pengunjung/petugas yang masuk dalam peternakan lebih banyak dibanding yang tidak dengan presentase 59.57\%.Setiap petugas/pengunjung yang ingin memasuki area petenakan diwajibkan melalui penyemprotan dengan desinfektan. Tujuan penggunaan desinfektan ini adalah untuk membunuh mikroorganisme patogen yang mungkin terbawa oleh kendaraan, karyawan/staf/pengunjung (Direktorat Pembinaan Sekolah Menengah Kejuruan, 2014). Berarti sebagian peternak telah menyadari hal tersebut dan menerapkannya dalam area peternakannya. Namun, dalam hal ini ada beberapa peternak belum menerapkan disebabkan kurangnya kepedulian dan peralatan desinfeksi.

\section{b. Adanya Desinfeksi Terhadap Kendaraan dan Peralatan Sebelum Masuk}

Setiap kendaraan yang akan memasuki area peternakan wajib melakukan desinfeksi karena kendaraan dapat membawa penyakit/virus dari luar area peternakan. Hal ini bertujuan agar mengurangi penyebaran agen penyakit. Berdasarkan grafik diatas dapat diketahui bahwa penerapan Desinfeksi terhadap kendaraan dan peralatan sebelum masuk di Kecamatan Panca Rijang tidak menerapkan dengan presentase 61.7\%. Setiap kendaraan dan peralatan yang akan memasuki area peternakan wajib melalui penyemprotan dengan desinfektan karena rentan membawa agen penyakit dari luar farm. Menurut (Deptan RI, 2008) Pembatasan secara ketat keluar masuk orang/tamu/pekerja dan kendaraan dari atau ke lokasi peternakan setiap orang yang masuk atau keluar peternakan harus mencuci tangan dengan sabun atau desinfektan. Hadi (2003) menambahkan Agen penyakit bisa masuk melalui Terbawa melalui debu, bulu-bulu atau sayap, dan kotoran (manure) pada peralatan dan sarana lain seperti truk, kandang ayam, tempat telur dll. Hal ini berarti peternak telah 
menerapkan hal tersebut dan telah sadar akan pentingnya desinfeksi kendaraan dan peralatan.

c. Tidak Meminjamkan Peralatan Kandang dengan Peternak lainnya

Peralatan kandang yang digunakan dalam kandang tidak boleh berpindah-pindah kandang agar mengurangi terjadinya penyebaran penyakit. Berdasarkan grafik diatas dapat diketahui bahwa Responden di Kecamatan Panca Rijang Tidak meminjamkan peralatan kandang dengan peternak lainnya dengan presentasi 97.87\%.Peralatan kandang yang digunakan tidak diperbolehkan keluar dari area farm karena akan berakibat terjadinya penyebaran penyakit. Setiap pekerja atau orang di unit usaha pangan bertanggung jawab menjaga segala sesuatu tetap bersih dan saniter. Pembersihan peralatan yang efektif mengurangi peluang terjadinya kontaminasi selama penyiapan, penyimpanan, dan penyajian. Pembersihan berarti penghilangan kotoran-kotoran yang kasat mata (visible) dari permukaan peralatan dan bahan. Saniter berarti sehat atau higienis. Hal ini mencakup pengurangan sejumlah mikroorganisme patogen pada permukaan peralatan dan bahan sampai tingkat aman bagi kesehatan. Sesuatu yang saniter tidak memiliki risiko bagi kesehatan manusia (McSwane et al. 2000). Johari (2004) menambahkan Pengendalian lalu lintas diupayakan untuk men-screening orang, alat,barang dan hewan lain, agar kegiatan lalu lintas yang dilakukannya tidakmenyebabkan masuknya patogen ke dalam farm. Berarti sebagian besar peternak menerapkan hal tersebut, dan peternak dalam hal ini telah memiliki peralatan kandang sendiri sehingga tidak perlu meminjam/meminjamkan peralatannya.

\section{KESIMPULAN}

Berdasarkan hasil penelitian yang telah dilakukan, maka diperoleh kesimpulan bahwa tingkat penerapan biosecuriti pada peternakan ayam petelur di Kecamatan Panca Rijang Kabupaten Sidrap yaitu tingkat penerapan isolasi sebesar 61.24 \%, Sanitasi sebesar 77.38\% dan Pengawasan Lalu Lintas sebesar 77.06\%.

\section{DAFTAR PUSTAKA}

Abidin, Z. 2003. Meningkatkan Produktivitas Ayam Ras Petelur. PT. Agromedia Pustaka, Jakarta.

BPS , 2015. Populasi ternak Sulawesi Selatan Tahun 2015.

2017. Kabupaten Sidrap dalam angka 2017. Pemda Kabupaten Sidrap, Sidrap.

Dinas Peternakan dan Perikanan Kabupaten Sidrap. 2012. Data Populasi. Populasi Ayam Ras Petelur. 
Direktorat Pembinaan Sekolah Menengah Kejuruan, 2014. Dasar-dasar Kesehatan Ternak.

Direktorat Jenderal Peternakan. 2005. Bagaimana Terhindar dari Flu Burung (Avian Influenza). Jakarta

Departemen Pertanian Republik Indonesia. 2006. Restrukturisasi Sistem Perunggasan Di Indonesia.

Departemen Kesehatan Republik Indonesia. 2001. Kumpulan Modul Kursus Penyehatan Makanan Bagi Pengusaha Makanan dan Minuman Jakarta: Yayasan Pesan

Fadilah, R. danPolana, A. 2004. Aneka Penyakit pada Ayam dan Cara Mengatasinya. PT. Agromedia Pustaka. Jakarta. Hal 14-20

Grimes T, Jackson C. 2001. Code of Practice for Biosecurity in the Egg Industry. Barton Australia; Rural Industries Research and Development Corporation. (Online) (http:/ / www.aecl.org/images/File/Producer\%20Resources/Bios ecurity \%20Code\%20of\%20Practice.pdf., diakses 2 Juni 2018).

Hafez, E.S.E. 2000. Semen Evaluation in Reproduction In FarmAnimals7thEd. LippincottWiliams and Wilkins. Philadelphia

Irawan, B. 2007. Pengembangan Checklist Untuk Audit Biosekuriti, Higiene, Dan Sanitasi Peternakan Petelur. Bogor : IPB.

Johari, S. 2004. Sukses Beternak Ayam Ras Petelur. PT. Agromedia Pustaka. Jakarta.

Jefrey, J.S. 1997. Biosecurity rules for poultry flocks. World Poultry 13(9): 101

.2006. Biosecurity for poultry flocks. Poultry Fact Sheet No 26.http:/ / www.vetmed.ucdavis.edu/vetext/INFPO_Biosecurity.html, diakses 2 Juni 2018).

Lukman, W. 2008. Pengetahuan Peternak Sebagai Prospek Pengembangan Usaha Peternakan Sapi Potong di Kecamatan Surade Kabupaten Sukabumi. Fakultas peternakan Institut pertanian Bogor. Bogor.

Litbang Pertanian, 2004. Sosio-Economic Impact Assesment of the Avian Influenza Crisis on Poultry Production System in Indonesia.

Marriott NG. 1999. Principles of Food Sanitation. 4th Ed. Gaithersburg,Maryland: Aspen

McSwane D, Rue N, Linton R. 2000. Essentials of Food Safety and Sanitation. 2nd Ed. Upper Saddle River: Prantice Hal.

Notoatdmojo. 2003. Pengertian Pengetahuan. Fakultas Peternakan, Universitas Diponegoro, Semarang

Swacita, I. Bagus, 2017. Bahan Ajar Kesehatan Masyarakat Veteriner. Biosekuriti. Bali :UniversitasUdayana.

Yuwanta, T. 2000. Dasar Ternak Unggas. Handout. Fakultas Peternakan, Universitas Gadjah Mada, Yogyakarta. . 2010. Telur dan Kualitas telur. Gajah Mada University Press, Yokyakarta. 